\title{
The Concept of Outdoor Play Safety in Early Childhood
}

\author{
Cucun Yunianingsih ${ }^{1, *}$, Euis Kurniati ${ }^{2}$ \\ 1,2 Postgraduate School, Indonesia University of Education, Bandung, Indonesia \\ *Corresponding author. Email: cucunyunianingsih214204@upi.edu
}

\begin{abstract}
This study aims to describe the concept of play safety for early childhood in outdoor playgrounds. Safety is an important component in facilitating play activities for early childhood. This study is conducted due to the importance of the research which is related to children's safety when they are playing in an open playground. Children should be able to explore the environment of the open playground freely. Therefore, the safety and the security of the rides used in the playground have to be made certain. The method used in writing this article is literature review by studying various theories related to the concept of play safety for early childhood in outdoor playgrounds. The result of this study is expected to provide information regarding the importance of the concept of play safety in outdoor playgrounds. Therefore, surveillance, maintenance, and periodic evaluation need to be done to keep the children safe.
\end{abstract}

Keywords: Play safety, early childhood, outdoor playground.

\section{INTRODUCTION}

Playing in an outdoor playground brings a lot of benefits for early childhood. Children can do some activities, such as walking, running, hanging, jumping, climbing, etc., to train their motoric skills, so their body will be strong enough to perform physical tasks in everyday life. In addition, playing in an outdoor playground trains the children in self-control in order to manage their emotion. This is due to the habituation of carrying out physical activities that makes them capable of managing and controlling their emotions well. All this time, the various studies conducted in Indonesia related to outdoor playground mostly discuss the children development aspect, the study of outdoor playing benefits for rough motoric skills [1], as well as the children development in cognitive, language, emotional, and social aspects [2], while only few of them related to safety in children playground.

The complete facilities and infrastructure availability as well as their maximized usage are some supporting factors in the success of the education program [3],[4]. The Regulation of The Minister of Culture and Education no. 137 of 2014 mentions the implementation of goodquality Early Childhood Education requires adequate facilities that meet the standards of Early Childhood Education. This is in accordance with the mandate stated in the article 45 paragraph 1 of Law no. 20 of 2003 that each formal or non-formal education unit provides facilities and infrastructure that fulfil the needs of the educators, based on the growth and the development of students' potential in physical, intellectual, social, emotional, and psychology [5]. If the setup of the outdoor playground is carried out safely and attractively, it may encourage children to be enthusiastic about adventure and to explore all their potential [6]. It is mandatory for every kindergarten to prioritize and apply the concept of children play safety when they are in the playground, in order to minimize the risk of injury to the children.

There are two main functions for the children to play in the outdoor playground. First: all the potential in the children must be developed optimally, secondly: due to the limited space and time given by the parents to the children, they are often kept away from playing rides, due to excessive worries, as well as the facilities of the outdoor playground, which is less supportive, so that it may pose a risk of injury to the children [7].

The risk of injury experienced by the children when playing is mostly caused by falling [8] There is data found as follows: More than a half of majority of children aged between 5 to 9 years, experience falling injuries which are related to the playground. Children aged 4 years and under are more likely to have injuries to their head and face. Children of 5 to 14 years of age are more likely to experience injuries to their arms and hands. Children who fall on concrete or asphalt are more than twice as likely to be injured compared to those who fall on shock absorbing materials. 
According to the National Playground Safety Institute, the dangers that occur in the playground, which is related to the environment, equipment, and lack of supervision, is due to several things, namely: the very close distance of each equipment, the lack of supervision, the unsuitable playing equipment for the children's age, and the lack of maintenance of the playing equipment [9].

The previous research related to this study, the research on safety rules of outdoor playgrounds for preschoolers at LKIA 3 Kindergarten in Pontianak, resulted in the findings such as: The outdoor playing environment was not safe for the children. It could be seen in the rough surface and the playing equipment which were close to each other. Therefore, these might cause risk of injuries to the children [10].

From the statement above, it can be said that children often experience falling injuries in outdoor playgrounds. This is due to the unfulfilled standards of safety in the playground. The worries felt by parents, that they limit their children when they are playing in outdoor playground, is solely in order to keep their children away from the risk of injuries, whereas in terms of benefits, playing in outdoor playground helps supporting children's physical growth. Therefore, the safety of the outdoor playground is the part to be prioritized and paid attention by the schools and institutions, especially early childhood education, in relation to the concept of play safety for children in outdoor playground, in order to minimize the occurrence of accidents on children and eliminate parents' worries when their children are playing in outdoor playground. Based on the description of the above phenomenon, the authors are interested in examining more deeply regarding the concept of play safety for early childhood in outdoor playgrounds.

This article applies the method of literature review or the study of several theoretical sources related to the concept of play safety for early childhood in outdoor playgrounds. The process of writing the literature review consists of several stages, such as planning, organizing, drafting, editing, and redrafting [11].

Planning Stage. In this process, the authors define the topic and specifically review the selected literature. The two steps are related to each other as the chosen theme later determines which literature to be identified. Similarly, the result of literature search determines the topic of discussion. In this planning stage, the authors select articles and other relevant references by visiting libraries, browsing the internet, or by searching literature resources to find theories which are relevant to the topic of the article, such as those which are related to the concept of play safety for early childhood in the outdoor playground.

Organizing Stage. In this organizing process, the authors analyse and evaluate the literature references that meant to be studied. When the articles about the concept of play safety for early childhood in outdoor playgrounds are considered enough, then the authors carry out the reading and analysing stage of the various articles, and make the result of the analysis into a new organizational framework and provide evaluation remarks on their own notes.

Drafting Stage. In this drafting process, the authors compile the first draft of the review findings about the concept of play safety for early childhood in outdoor playgrounds from various literatures.

Editing Stage. In the editing process, the authors ensure whether or not the result of the first review which has been compiled is complete and true.

Redrafting Stage. In this redrafting process, the authors compiled and rewrote the draft, based on the editing result.

\section{THE APPLICATION OF THE CONCEPT OF PLAY SAFETY FOR CHILDREN IN OUTDOOR PLAYGROUND}

\subsection{Planning}

In the online Indonesia Dictionary (KBBI), "Planning as a process, an action, a way of planning," In relation to the play safety for children in outdoor playgrounds, planning can be interpreted as the process of setting up a plan and selecting facilities and infrastructure for outdoor playground that fulfils the children's needs and meets the standard.

In the Norms, Standards, Procedures, and Criteria (NSPC) guidelines for the facilities of early childhood education, there are principles as follow: They are made of safe and healthy materials for the children, in terms of shape and size according to the needs and the children's age, so that they may support children's growth and development; they must have elements of education that motivate and stimulate children to explore and do some experiment [13].

In reality however, many schools or institutions for early childhood education have not fulfilled the requirement based on NSPK standards. This is due to the lack of cooperation. The foundation is the one responsible for planning and procurement, while the teachers and principals are the ones who carry it out. This causes miscommunication to occur frequently. As teachers noticed the broken toys and had to be repaired immediately, but they were hampered by having to wait for a long time as the foundation had not followed up. In the process of planning and determining the environment for a playground, it is better for the foundation, principals, and teachers to work together, hand in hand, and think about it seriously in order to support children's growth and development [14]. As for the parts of the planning for outdoor playing environment are as follows: 
1. It has to meet the safety regulations, 2 . The playing equipment must be in accordance with children's characteristics, 3 . It must be set to meet the children's needs.

\subsection{Management \& Maintenance}

The availability of complete playing equipment may support the process of children growth and development. Every school and institution should properly conduct a regular management and maintenance, so that the playing equipment will not be harmful to the children.

In the previous study, the following problems were found in African countries: There were very few children playing outside. There were demands from parents in achieving academics. There was a lack of understanding on how important it was to care for a children playground [15]. The managers/owners of educational institutions only thought about gaining as much profit as possible, so that they did not maintain or repair the children's playground.

In supporting children's physical activity, it is important to provide a safe outdoor playground for children. However, in the meantime, there are still many schools, especially at the level of early childhood, having challenges in relation to the management of outdoor playgrounds, such as the problems found in the research in Kenya and Africa. This is similar to the survey conducted on 15 kindergartens in the sub-district of Bubutan, Surabaya [16]. It found that the outdoor playgrounds were mostly lacking in service and maintenance. On the contrary, the research about outdoor playground management at LKIA, which was conducted by Pontianak, resulted as follows: the management of the outdoor playground had been done well. There was a large outdoor playground and the playing equipment was set appropriately and was conditioned as needed, making the children feel free and comfortable to play outside. The maintenance had also been well implemented by keeping the outdoor playing equipment clean. [17]. This is in line with the safety principles of outdoor playground at Safety Park Batu Malang as follow: it had a safe and soft cover for children, there was a large playground area, the rides were placed at the proper distance, each playing equipment was set to the children's age, and the management was carried out regularly and professionally [18].

\subsection{Children Safety Education when Playing in Outdoor Playground}

Personal safety education for children is very important and needs to be introduced at an early age, so that the children have skills for their own safety when facing danger [19]. Basic knowledge about safety needs to be given before the children start to play, in order to avoid the risk of accidents to the children, as happened at
Immanuel Kindergarten where some children suffered from injuries while playing, such as: getting hit by friends, getting hit by playing equipment, falling down. There were even some children who used the equipment without complying the rules. This happened due to the lack of understanding and explanation on the children before playing in the outdoor playground [20]. When the children are in the school environment, the teacher should be able to carry out guiding process for the children related to safety education, so that the children acknowledge such things as follow: The existence of rules for play safety, the forms of danger and the solution to overcome them, where to keep the toys in order not to cause harm, so that they are trained to use the playing equipment properly [21]

There are four stages of the process of giving the children knowledge for their safety when they are playing, namely: 1. Danger Identification. At this stage, the teacher may explain to children the type of dangers that may occur. So that the information is quickly accepted by the children, it should be delivered in an interesting and fun way, for instance: through song by singing, watching together, etc. 2. Danger Survey. At this stage, all the teacher needs to do is explain the rule of conducting the survey. Divide children into small groups, invite them to see the around school environment, then the children may draw the potentially dangerous location in the school. This is intended so that the children know their environment better. Stage 3 is Danger Mind Map. Before starting, the teacher should explain the rules to the children. Stage 4 is Avoiding Danger. At this stage, the child may talk about the pictures they have made in relation to danger, then the children and the teacher draw the conclusions [22].

The most important point to convey to the children is that they are not the only one playing in the playground, there are other friends too. Children need to understand that they must not let their friends get hurt when they are playing. Therefore, they should be introduced: 1 . The concept of fair play: they have to obey rules, starting from waiting in line, willing to take turns, and being kind when playing, not pushing their friends in playing slides, swings, and so on. 2. Play by keeping themselves safe by using the playing equipment properly and correctly, for instance when they are playing swings, they should be seated, and should not be standing.

\section{CONCLUSION}

The concept of play safety for early childhood in outdoor playgrounds can be done by making prior plans. Selecting and determining the right playing equipment, meeting the standard of Early Childhood Education facilities which are in accordance to the children's age and development. Playing equipment is made of safe and healthy material, the spacing and placement must be set appropriately, and playing equipment should not cause 
harm to the children. The playing equipment is also designed to be attractive, safe, and comfortable to support children's skills in motoric, cognitive, and social emotional. Supervising the children when they are playing is mandatory for teachers in order to minimize accidents, because when children are in a school environment, they are the teachers' responsibility. Regular maintenance of playing facilities and infrastructure, as well as education regarding their safety, must be done and given before they start playing in the playground. The knowledge is given in the form of rules, how to use playing equipment well to maintain safety for themselves and others.

\section{REFERENCES}

[1] Nizrina EH. Outdoor Terhadap Kemampuan Motorik Kasar Anak Usia 4-5 Tahun. 2019;6:4-5.

[2] Herlinda S. Pembelajaran paud dengan strategi out door. Kindergarten: Journal of Islamic Early Childhood Education. 2018 Jul 30;1(1):67-74.

[3] Nuraini L, Yuniarni D. Analisis pemanfaatan sarana dan prasarana pendidikan di tk pertiwi kecamatan tebas. 2020;9(7):1-9.

[4] Permendikbud Nomor 137 Tahun 2014 tentang Standar Nasional Pendidikan Anak Usia Dini.

[5] Undang-undang Nomor 20 Tahun 2003 tentang Sistem Pendidikan Nasional.

[6] Park MH, Riley J. Play in Natural Outdoor Environments: A Healthy Choice. Dimensions of Early Childhood, 2015;43(2):22-28.

[7] Asmawati, Luluk, dkk. Pengelolaan kegiatan pengembangan Anak Usia Dini. Jakarta: Departemen Pendidikan Nasional. 2008.

[8] Rommesmo S, Garden-Robinson J, Barnhart T. Is your playground safe for kids? Fargo: North Dakota University. Available from: https:/library .ndsu.edu/ir/bitstream/handle/10365/5184/fn1374co lor.pdf? sequence $=1$.

[9] Yule M. Playing it safe with reactors. Physics World, 2010;23(10):60-61. Available from: https://doi. org/10.1088/2058-7058/23/10/44

[10] Khairunnisyah D, Ali M. Aturan keamanan area bermain outdoor anak usia prasekolah di TK LKIA III Pontianak. Jurnal Pendidikan dan Pembelajaran Untan, 2015;4(11):1-10.

[11] Galvan JL. Mellisa G. Writing Literature Reviews, A Guide for Student of the Social and Behavioral Sciences Seventh Edition. New York: Routledge; 2017.

[12]Perencanaan (Def.1) (n.d). Kamus Besar Bahasa Indonesia (KBBI) Online. [Cited 2020 September]. Available from: https://Kbbi.Web.i d/perencanaan.11.
[13] Yolanda E, Suryana D. Facilities and infrastructure management of early childhood education reviewed from government policies and headmaster managerial skill. Unpublished manuscript. Padang: Universitas Negeri Padang. Nd.

[14] Susilowati R. Strategi Belajar Outdoor Bagi Anak PAUD. ThufuLA: Jurnal Inovasi Pendidikan Guru Raudhatul Athfal. 2018 Dec 17;2(1):65-82.

[15]Wijenje, Asaji P, Waithaka E. The role of playground facilities on preschool children's participation in outdoor play activities in Mombasa country Kenya. European Journal of Education Studies. 2018;4(10):214-26. Available from: https://doi.org/10.5281/zenodo.1317536.

[16] Silmi RK, Widayati S. Survei sarana dan prasarana outdoor di taman kanak-kanak Kecamatan Bubutan Surabaya. PAUD Teratai. 2014 Jan 6;3(3):1-7.

[17] Andinna K, Miranda D. Analisis pengelolaan area bermain outdoor pada anak usia 4-5 tahun di TK LKIA Pontianak. Jurnal Pendidikan dan Pembelajaran Untan. 2015;4(11):1-11.

[18]Darmawan GR, Sufianto H, Murti A. Kids safety park, Batu: Penerapan konsep keselamatan pada pengguna taman bermain anak. Jurnal Mahasiswa Jurusan Arsitektur, 2016;4(4):1-10. Available from: http://arsitektur.studentjournal.ub.ac.id/index.php/j $\mathrm{ma} / \mathrm{article} / \mathrm{view} / 277$.

[19] Abivian M. Pentingnya keterampilan mempertahankan dan menyelamatkan diri (survival and safety skills) pada anak. Prophetic: Professional, Empathy and Islamic Counselling Journal. 2019;2(1):1-6.

[20] Sholihah Q, Sari SIK, Pramuditha VP, Prayoga HD, Hanafi AS. Evaluation and strategic planning of playground for kids to reduce the accident risk (case study in Immanuel kindergarten Batu city). Indian Journal of Public Health Research and Development. 2019;10(2):467-72. Available from: https://doi.org/ 10.5958/0976-5506.2019.00335.8.

[21]Adi BS. Pendidikan Keselamatan di Sekolah. Yogyakarta: PPSD UNY. 2008.

[22] Widayati T. Pendidikan keselamatan diri anak usia dini (studi kasus di kelompok bermain (KB) Gaharu Plus Kutai Kartanegara). Jurnal Ilmiah VISI PGTK PAUD dan Dikmas. 2018;13(2):113-22. Available from: https://doi.org/10.21009/JIV.130. 